ISSN 0103-5150

Fisioter. Mov., Curitiba, v. 30, n. 2, p. 297-306, Apr./June 2017

Licenciado sob uma Licença Creative Commons

DOI: http://dx.doi.org/10.1590/1980-5918.030.002.A010

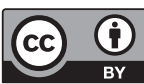

\title{
Idiopathic scoliosis: Static analysis of the influence of shim use on postural angles
}

\author{
Escoliose Idiopática: Análise estática da influência \\ do uso de calço nos ângulos posturais
}

\author{
Jaqueline Santos Silva, Ângela Kazue Morita, \\ Célia Aparecida Stellutti Pachioni, Cristina Elena Prado Teles Fregonesi, \\ Claúdia Regina Sgobbi de Faria, Dalva Minonroze Albuquerque Ferreira*
}

Universidade Estadual Paulista (UNESP), Presidente Prudente, SP, Brazil

\begin{abstract}
Introduction: Scoliosis is characterized as a three-dimensional deformity. In this scenario, the use of shims can promote correction of postural imbalances. Objective: To verify the static changes associated with unilateral manipulation of shims in idiopathic scoliosis. Methods: Two experimental groups composed of participants with scoliosis with double and single curves, and a control group of participants without scoliosis. 10 reflective markers were used, filmed for 15 seconds in the static position in three conditions (no shim; low shim of $1 \mathrm{~cm}$, and high shim of $3 \mathrm{~cm}$ ) on the right and left foot. The following postural angles were calculated: alpha 1, alpha 2, alpha 3, and alpha 4. Results: There were differences in the shim condition between the control group (CG) and experimental scoliosis with "S" (GES) for alpha 2 and 4 and Scoliosis "C" (GEC) for alpha 2. For shims under the right foot, there were differences between the control group and GES for alpha 4 and the GEC for alpha 1, 2 and 4, and between shims for the GES for alpha 3 and 4. Shims under the left foot were responsible for significant differences between the control group and the GES and GEC groups. Conclusion: These static postural changes indicate that scoliosis curves show adaptability and postural
\end{abstract}

\footnotetext{
* JSS: MS, e-mail: jaqueee-santosss@hotmail.com AKM: BS, e-mail: angela.morita@yahoo.com.br CASP: PhD, e-mail: pachioni@fct.unesp.br CEPTF: PhD, e-mail: cristina@fct.unesp.br CRSF: PhD, e-mail: sgobbi@fct.unesp.br DMAF: PhD, e-mail: dalva@fct.unesp.br
} 
reorganization in response to manipulation with shims, and the greatest influence is seen in the lower segments, both in simple and double curves. According to the results it is concluded that residual scoliotic curvatures have flexibility that allows postural adjustment with shims.

Keywords: Scoliosis. Physical Therapy Specialty. Postural Balance. Spine.

\section{Resumo}

Introdução: A escoliose é caracterizada como uma deformidade tridimensional. Neste cenário, o uso de calços pode promover correções de assimetrias posturais. Objetivo: Verificar as alterações estáticas associadas com manipulações unilaterais de calços na escoliose idiopática. Métodos: Dois grupos experimentais compostos de participantes com escoliose de curvas duplas e simples, e um grupo controle de participantes sem escoliose. Foram utilizados 10 marcadores reflexivos, filmados durante 15 segundos na posição estática em três condições (sem calço; com calço baixo de $1 \mathrm{~cm}$; e alto de $3 \mathrm{~cm}$ ) sob o pé direito e esquerdo. Foram calculados ângulos posturais: alfa 1, alfa 2, alfa 3 e alfa 4. Resultados: Houve diferenças na condição sem calço, entre grupos controle (GC) e experimental com escoliose em "S" (GES) para alfa 2 e 4 e com escoliose em "C" (GEC) para alfa 2. Calços sob o pé direito, houve diferenças entre os grupos controle e GES para alfa 4 e GEC para alfa 1, 2 e 4, e entre calços para GES para alfa 3 e 4 . Calços sob o pé esquerdo foram responsáveis por diferenças significantes entre grupos controle e GES e GEC. Conclusão: Estas alterações posturais estáticas indicam que curvas escolióticas apresentam capacidade de adaptação e reorganização postural em resposta à manipulação dos calços, sendo que a maior influência é observada nos segmentos inferiores, tanto em curvas simples como duplas. De acordo com os resultados observados, conclui-se que as curvaturas escolióticas apresentam flexibilidade residual que permite ajustes posturais na presença de calços.

Palavras-chave: Escoliose. Fisioterapia. Equilíbrio Postural. Coluna Vertebral.

\section{Introduction}

Scoliosis is a complex deformity that affects the three anatomical planes $(1-3)$. This three-dimensional deformity becomes fixed due to mechanical imbalance, regardless of reason, resulting in a discharge of asymmetric weight, tending to aggravation over time (3 - 5).

It is known that the Adolescent Idiopathic Scoliosis (AIS) is the most common type of scoliosis and manifests itself in the period of puberty, affecting approximately $2 \%$ of adolescents $(2,6)$. AIS can also be influenced by external factors such as the support base, whose disturbance may have an influence on posture and the balance of the spine $(7,8)$.

In this scenario, care and analysis of the feet are relevant, since they have a fundamental role in static and dynamic balance. The plantar region has a variety of neuro-sensors that are sensitive to variations in deformation. The information resulting from these neuro-sensors is quickly transmitted to the central nervous system. In response to these stimuli, the central nervous system regulates the tension of the postural muscles and regulates body oscillations through the extrinsic and intrinsic foot muscles (9, 10). To produce stimuli in the plantar region, support bases (8), insoles (11 - 13), heel elevations (7), and shims $(14,15)$, trigger corrections of some postural variables and seek to correct asymmetries.

Evaluation of scoliosis is through postural assessment or kinesiological examination and can be complemented with the Adams test to verify the presence of gibbosity (16). In many studies, clinical measurement of gibbosity is performed by means of an adapted wooden device $(17,18)$, manufactured based on the description of Surós (19). In addition, radiological examination is used to confirm the clinical findings (20), using for this purpose the Cobb angle measure $(21,22)$.

Due to the importance of these types of interventions in the treatment of idiopathic scoliosis, various methods have been developed, such as the use of support bases (shims and insoles). The use of shims promotes an upward correction of asymmetries, 
which, in addition to preventing the development and compensation of postural deviations, avoids aggravation of degenerative injuries and pain in the body segments $(9,23)$. Faced with the above, the present study was constructed to answer questions on the topic described, as well as fill gaps in the literature on the influence of shim use in the correction of asymmetries in patients with idiopathic scoliosis.

\section{Methods}

\section{Characterization of the sample}

This is a cross-sectional study. In total, 42 subjects were evaluated, divided into three groups: control group (GC), composed of 10 participants without scoliosis [age $20.2 \pm 1.13$ years; weight $60.22 \pm 13.36$ kg; height $1.64 \pm 0.08 \mathrm{~m}$; Body Mass Index (BMI) = $\left.22.06 \pm 2.27 \mathrm{~kg} / \mathrm{m}^{2}\right], 9$ female and 1 male; experimental group with scoliosis "S" (GES) consisting of 22 participants diagnosed with idiopathic scoliosis and double curvature [age $19.00 \pm 2.96$ years; weight $54.98 \pm 9.71 \mathrm{~kg}$; height $1.64 \pm 0.08 \mathrm{~m}$; BMI $20.23 \pm 2.70$ $\mathrm{kg} / \mathrm{m}^{2}$ ), 19 female and 3 male; experimental group with scoliosis "C" (GEC), composed of 10 participants diagnosed with idiopathic scoliosis and simple curvature [age $19.50 \pm 1.35$ years; weight $54.56 \pm 8.93$ $\mathrm{kg}$; height $1.64 \pm 0.09 \mathrm{~m}$; BMI $20.22 \pm 2.44 \mathrm{~kg} / \mathrm{m}^{2}$ ), 7 female and 3 male; both experimental groups presented idiopathic scoliosis with angles greater than 10 degrees, confirmed through measurement of the Cobb angle in the radiological examination, characterizing structural curves $(24,25,26)$. Participants were allocated for convenience and recruited from a group for strengthening exercises in carriers of idiopathic scoliosis directed by the same laboratory. In addition, the type of curve (thoracic, lumbar, or thoracolumbar) and side of the curve (right or left) were evaluated, totaling in the GES $(17.8 \pm 27.8$ degrees) 18 individuals with thoracic type scoliosis to the right and lumbar to the left, and only 4 individuals with thoracic scoliosis to the left and lumbar to the right. In the GEC $(12.3 \pm 1.94$ degrees $)$ totaling 3 individuals with thoracic scoliosis to the right, 1 with lumbar scoliosis the left, 1 with thoracolumbar scoliosis to the right, and 5 with thoracolumbar scoliosis to the left.

The study was approved by the Research Ethics Committee of the Faculty of Science and Technology,
UNESP, Presidente Prudente Campus - CEP 124/2009. Volunteers and their parents or guardians, signed an Informed Consent, agreeing to participate in the study. The exclusion criteria were: using prosthetics and/or orthotics, having undergone surgery in the spine, being in a gestational stage, presenting a difference greater than $1.50 \mathrm{~cm}$ in the length of the lower limbs, and being a carrier of scoliosis with known etiology.

\section{Study Design}

The individuals underwent a clinical evaluation to measure gibbosity. This measure was taken by means an instrument consisting of an adapted water level and wooden ruler ${ }^{19}$ intended to measure, in millimeters, trunk asymmetries observed during the Adams test $(17,18,20,27)$. When the values were greater than $5 \mathrm{~mm}$, the participants were instructed to undergo a radiological examination to confirm the diagnosis of structural scoliosis and, if so, they became part of one of the groups according to the type of scoliosis.

After the initial evaluation, participants attended the Applied Physical Therapy Laboratory of Human Movement, Faculty of Science and Technology/ UNESP - Presidente Prudente, to carry out the experimental procedures. With participants in swimming clothing, 10 reflective markers, $13 \mathrm{~mm}$ in diameter were fixed at the following anatomical points of the spine: spinous process of the seventh cervical vertebra (C7); the second (T2), fourth (T4), sixth (T6), eighth (T8), tenth (T10), and twelfth (T12) thoracic vertebrae; spinous process of the second (L2), and fourth (L4) lumbar vertebrae, and the medial sacral crest (S1) (28 - 30). After placement of the markers, the participants assumed the "nominal feet position" (31) positioning themselves on a drawing of the plantar impression in EVA to ensure that the same position was maintained in all attempts.

Participants were filmed by three cameras arranged within the collection area and the direction of the coordinate system of volume calibration ( $\mathrm{x}, \mathrm{y}$, and $\mathrm{z}$ axes) was used to perform the calibration and filming. The frequency of acquisition of the images collected by the cameras was $60 \mathrm{~Hz}$. Three spotlights were fixed behind each camera to allow reflection of the markers fixed to the participants.

The order of conditions was previously selected from the following: without shim; $1 \mathrm{~cm}$ low shim 
under the right foot; $1 \mathrm{~cm}$ low shim under the left foot; $3 \mathrm{~cm}$ high shim under the right foot; $3 \mathrm{~cm}$ high shim under the left foot. In total, 15 seconds was filmed for each condition. Between the conditions, and when necessary, there was a short break for the participants to rest in order to prevent or minimize any muscle fatigue effect.

Preceding the collection of images, a 15 second film of the calibration system was carried out, consisting of a three-dimensional reference system with 12 control points and volume of $1.07 \times 1.66 \times 1.23$ $\mathrm{m}$ (length, height, and depth respectively), to obtain the reference points necessary to process the camera images in the metric system.

For synchronization of the three cameras, a device with an LED powered by a trigger was used. The activation occurred at the beginning of each attempt, and the LED lighting was visible by the three cameras, allowing the synchronized analysis of the images from each trial.

\section{Data processing}

The images were processed by the software Ariel Performance Analysis System (APAS, version 1.4), using the modes CapDV, Trimmer, Digitize, Transform, Filter and Display. This treatment allows identification of the position of the markers on the axes of the $\mathrm{x}, \mathrm{y}$ and $\mathrm{z}$ coordinates, and thus the angular values on the frontal plane.

\section{Postural angles}

Figure 1 shows the convention used to calculate the angles based on studies by Engsberg et al. (28) and Feipel et al. (29), adapted to measure the postural angles in the present study. Four postural angles of the spine were evaluated in the frontal plane: $\alpha 1$, $\alpha 2, \alpha 3$ and $\alpha 4$, formed by the markers T2T4-T4T6, T6T8-T8T10, T10T12-T12L2 and L2L4-L4S1, respectively. For standardization, these angles were always measured on the right side of the spine. The measurements of these angles have the function of evaluating the postural modifications in the spine, starting from the measurement of a basal reference angle of $180^{\circ}$, and the variations in these angles demonstrate the influence that the static position and change in shims produce in the spine of individuals with idiopathic scoliosis and GC individuals.

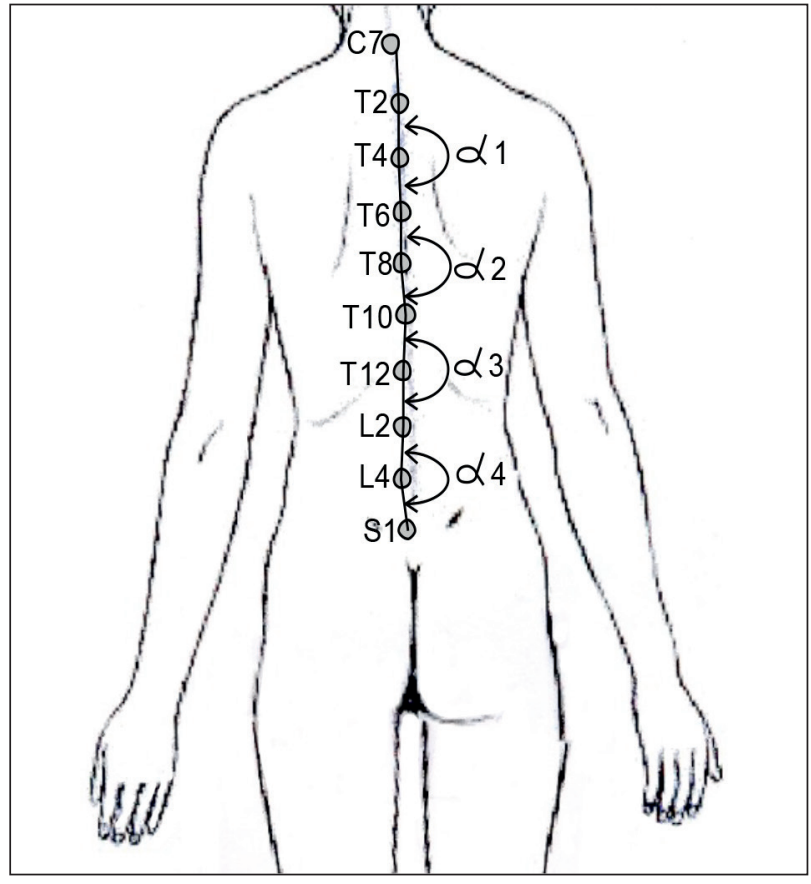

Figure 1 - Postural angles of the spine in the frontal plane: alpha angle 1, high thoracic (T2T4-T4T6), alpha angle 2, middle thoracic (T6T8-T8T10), alpha angle 3, thoracolumbar (T10T12-T12L2), and alpha angle 4, lumbar (L2L4-L4S1).

\section{Treatment and analysis of data}

The data obtained in the condition static posture maintenance without shim, were used to identify the configuration of postural angles in the orthostatic position and the absolute values of these were determined. Thus, the intermediate $5 \mathrm{sec}$ of the $15 \mathrm{sec}$ of images collected were digitized via the APAS and the mean and standard deviation of these angles were also calculated.

\section{Statistical analysis}

Analyses of variance (ANOVAs) were performed to compare the static condition, the control and experimental "S" group, and the control and experimental "C" group, in the conditions without shim, with a $1 \mathrm{~cm}$ low shim, and $3 \mathrm{~cm}$ high shim, under the right or left foot, which were treated as repeated measures. To compare the postural angles of the control and experimental groups, multivariate analyses were used (MANOVAs).

In the condition without shim, two One-way MANOVAs were used (group 2), with postural angles (mean of each of the angles $\alpha 1, \alpha 2, \alpha 3$ and $\alpha 4$ ) as dependent variables. 
In the condition low right shim $(1 \mathrm{~cm})$ and high right shim $(3 \mathrm{~cm}$ ) two MANOVAs ( 2 groups $\mathrm{x} 2$ shims) were used, with postural angles (mean of each of the angles $\alpha 1, \alpha 2, \alpha 3$ and $\alpha 4$ ) as dependent variables.

In the condition low left shim $(1 \mathrm{~cm})$ and high left shim $(3 \mathrm{~cm})$ two MANOVAs (2 groups $\mathrm{x} 2$ shims) were used, with postural angles (mean of each of the angles $\alpha 1, \alpha 2, \alpha 3$ and $\alpha 4$ ) as dependent variables.

All analyzes were performed using SPSS statistical software (version 17.0) and the level of significance adopted was 0.05 .

\section{Results}

The results obtained are presented in order to compare the GC with GES; and GC with GEC.

\section{Condition without shim}

Table 1 presents the mean values of alpha angles $(1, \alpha 2, \alpha 3$ e $\alpha 4)$ for the GC and GES in the without shim condition. MANOVA, involving the alpha angles, indicated differences for the group factor, Wilks' Lambda = $0.597, \mathrm{~F}(4,27)=4.560, \mathrm{p}=0.006$. The univariate analyses demonstrated differences in the alpha $2, \mathrm{~F}(1,30)$ $=4.251, \mathrm{p}=0.048$, and alpha 4 angles, $\mathrm{F}(1,30)=7.354$ $p=0.011$, and also a marginal difference for the alpha 3 angle, $F(1,30)=4.096, p=0.052$, however, in all cases the angles observed for the GES participants were higher than those observed for the participants in the GC.

Table 1 also shows the other MANOVA, involving the same alpha angles, however referring to the GC and GEC, which also indicated a difference for the group factor, Wilks' Lambda $=0.468, \mathrm{~F}(4,15)=4.269, \mathrm{p}=0.017$. The univariate analyses indicated differences only for the alpha 2 angle, $F(1,18)=5.487, p=0.031$, and the angle observed for the GEC participants was greater than that observed for the control group participants.

\section{Condition with right shim}

Table 2 presents the mean values of the alpha angles $(\alpha 1, \alpha 2, \alpha 3$ and $\alpha 4)$ for the GC and GES, in the condition with the right low shim and right high shim. The MANOVA, involving alpha angles, indicated a difference for the group factor, Wilks' Lambda $=0.653, \mathrm{~F}(4,27)=3.591, \mathrm{p}=0.018$. The univariate analyzes indicated a marginal difference for the alpha 2 angle, $F(1,30)=3.729, p=0.063$, and a difference for the alpha 4 angle, $F(1,30)=7.176 p=0.012$, where both angles observed for participants in the GES were higher than those observed for participants in the GC. The MANOVA also indicated a difference for the shim factor, Wilks' Lambda $=0.359, \mathrm{~F}(4,27)=12.038$, $\mathrm{p}<0.001$. The univariate analyzes indicated differences in the alpha $3, F(1,30)=9.573, p=0.004$, and alpha 4 angles, $F(1,30)=7.082, p=0.012$, and for both angles the values observed for the low shim condition were lower than those observed for the high shim condition.

Table 3 also presents the mean values of alpha angles ( $\alpha 1, \alpha 2, \alpha 3$ and $\alpha 4)$ for the GC and GEC groups, in the conditions with the right low shim and right high shim. The MANOVA indicated a difference only for the group factor, Wilks' Lambda $=0.441, F(4,15)=4.753$, $\mathrm{p}=0.011$. The univariate analyzes indicated differences in the alpha $1, \mathrm{~F}(1,18)=4.580, \mathrm{p}=0.046$, alpha $2, F(1,18)=5.711, p=0.028$, and alpha 4 angles, $F(1.18)=8.034, p=0.011$, and for all these angles, the values observed for participants of the GEC were higher than those observed for participants of the GC.

\section{Condition with left shim}

Table 4 presents the mean values of alpha angles $(\alpha 1, \alpha 2, \alpha 3$ and $\alpha 4)$ for the GC and GES groups in the conditions with low left shim and high left shim. The MANOVA, involving alpha angles, indicated a difference only for the group factor, Wilks' Lambda $=0.704, \mathrm{~F}(4,27)$ $=2.833, \mathrm{p}=0.044$. Although the MANOVA indicated $\mathrm{a}$ difference, the univariate analysis did not identify any differences in the alpha angles individually.

Table 5 also presents the mean values of alpha angles $(\alpha 1, \alpha 2, \alpha 3$ and $\alpha 4)$ for the GC and GEC groups in the conditions with low left shim and high left shim. The MANOVA indicated a difference for the group factor, Wilks' Lambda $=0.452, \mathrm{~F}(4,15)=$ $4.541, p=0.013$. Although the MANOVA indicated a difference, the univariate analysis did not identify any differences for the alpha angles individually. The MANOVA also indicated a difference for the shim factor, Wilks' Lambda $=0.430, \mathrm{~F}(4,15)=4.972, \mathrm{p}=$ 0.009 . The univariate analyzes indicated differences only for the alpha 4 angle, $F(1,18)=6.772, p=0.018$, and for this angle, the values observed for the low shim condition were lower than those observed for the high shim condition. 
Table 1 - Analyses of postural angles of the control and experimental "S" groups and the control and experimental "C" groups in the static condition without shim

\begin{tabular}{cccc}
\hline Postural Angles $\left(^{\circ}\right)$ & Group & Mean \pm Standard deviation & p-value (ANOVA) \\
\hline \multirow{2}{*}{ Alpha 1 } & GES & $3.10 \pm 2.30$ & 0.279 \\
& GC & $2.22 \pm 1.51$ & 0.183 \\
\hline \multirow{2}{*}{ Alpha 2 } & GEC & $3.82 \pm 3.33$ & $0.048^{*}$ \\
& GES & $3.84 \pm 2.05$ & $0.031^{*}$ \\
\hline \multirow{2}{*}{ Alpha 3 } & GC & $2.30 \pm 1.68$ & $0.052^{* *}$ \\
& GEC & $4.52 \pm 2.48$ & 0.499 \\
\hline \multirow{2}{*}{ Alpha 4 } & GES & $5.58 \pm 4.17$ & $0.011^{*}$ \\
& GC & $2.46 \pm 2.36$ & 0.119 \\
\hline
\end{tabular}

Note: GES: experimental group (scoliosis "S"); GC: control group; GEC: Experimental group (scoliosis "C"). ${ }^{*}$ Significant difference ( $\left.\leq \leq 0.05\right)$; ${ }^{* *}$ Marginal difference.

Table 2 - Analyses of postural angles with respect to the group and shim factors between the control and experimental "S" groups in the static condition with right shim

\begin{tabular}{|c|c|c|c|c|c|}
\hline \multirow[t]{2}{*}{ Postural Angles ( $\left(^{\circ}\right)$} & \multirow[t]{2}{*}{ Group } & \multicolumn{2}{|c|}{ Shim } & \multicolumn{2}{|c|}{$p$-value (ANOVA) } \\
\hline & & Low & High & p-group & p-shim \\
\hline \multirow{2}{*}{ Alpha 1} & GC & $2.11 \pm 1.53$ & $1.83 \pm 1.78$ & \multirow{2}{*}{0.153} & \multirow{2}{*}{0.119} \\
\hline & GES & $3.28 \pm 2.34$ & $2.90 \pm 2.10$ & & \\
\hline \multirow{2}{*}{ Alpha 2} & GC & $2.45 \pm 1.46$ & $2.31 \pm 1.66$ & \multirow{2}{*}{$0.063^{* *}$} & \multirow{2}{*}{0.675} \\
\hline & GES & $3.99 \pm 2.41$ & $3.97 \pm 2.49$ & & \\
\hline \multirow{2}{*}{ Alpha 3} & GC & $2.83 \pm 2.87$ & $4.50 \pm 2.83$ & \multirow{2}{*}{0.134} & \multirow{2}{*}{$0.004^{*}$} \\
\hline & GES & $5.58 \pm 4.17$ & $6.19 \pm 4.36$ & & \\
\hline \multirow{2}{*}{ Alpha 4} & GC & $1.93 \pm 1.12$ & $2.91 \pm 1.88$ & \multirow{2}{*}{$0.012^{*}$} & \multirow{2}{*}{$0.012^{*}$} \\
\hline & GES & $6.89 \pm 5.57$ & $7.94 \pm 6.16$ & & \\
\hline
\end{tabular}

Note: Mean \pm Standard deviation. GC: control group; GES: experimental group (scoliosis "S"); ${ }^{*}$ Significant difference $(p \leq 0.05) ;{ }^{* *}$ Marginal difference.

Table 3 - Analyses of postural angles with respect to the group and shim factors between the control and experimental "C" groups in the static condition with right shim

\begin{tabular}{|c|c|c|c|c|c|}
\hline \multirow[t]{2}{*}{ Postural Angles ( $\left(^{\circ}\right)$} & \multirow[t]{2}{*}{ Group } & \multicolumn{2}{|c|}{ Shim } & \multicolumn{2}{|c|}{ p-value (ANOVA) } \\
\hline & & Low & High & p-group & p-shim \\
\hline \multirow{2}{*}{ Alpha 1} & $\mathrm{GC}$ & $2.11 \pm 1.53$ & $1.83 \pm 1.78$ & \multirow{2}{*}{$0.046^{*}$} & \multirow{2}{*}{0.275} \\
\hline & GES & $4.43 \pm 3.42$ & $4.03 \pm 2.64$ & & \\
\hline \multirow{2}{*}{ Alpha 2} & GC & $2.45 \pm 1.46$ & $2.31 \pm 1.66$ & \multirow{2}{*}{$0.028^{\star}$} & \multirow{2}{*}{0.745} \\
\hline & GES & $4.71 \pm 2.65$ & $4.73 \pm 2.80$ & & \\
\hline \multirow{2}{*}{ Alpha 3} & $\mathrm{GC}$ & $2.83 \pm 2.87$ & $4.50 \pm 2.83$ & \multirow{2}{*}{0.340} & \multirow{2}{*}{0.201} \\
\hline & GES & $2.70 \pm 2.91$ & $2.27 \pm 2.87$ & & \\
\hline \multirow{2}{*}{ Alpha 4} & $\mathrm{GC}$ & $1.93 \pm 1.12$ & $2.91 \pm 1.88$ & \multirow{2}{*}{$0.011^{\star}$} & \multirow{2}{*}{0.706} \\
\hline & GES & $5.90 \pm 4.72$ & $5.51 \pm 3.40$ & & \\
\hline
\end{tabular}

Note: Mean \pm Standard deviation. GC: control group; GES: experimental group (scoliosis "S"); * Significant difference ( $\leq \leq 0.05)$. 
Table 4 - Analyses of postural angles with respect to the group and shim factors between the control and experimental "S" groups in the static condition with left shim

\begin{tabular}{|c|c|c|c|c|c|}
\hline \multirow[t]{2}{*}{ Postural Angles ( $\left.{ }^{\circ}\right)$} & \multirow[t]{2}{*}{ Group } & \multicolumn{2}{|c|}{ Shim } & \multicolumn{2}{|c|}{$\mathrm{p}$-value (ANOVA) } \\
\hline & & Low & High & p-group & p-shim \\
\hline \multirow{2}{*}{ Alpha 1} & GC & $2.22 \pm 1.36$ & $2.51 \pm 1.39$ & \multirow{2}{*}{0.282} & \multirow{2}{*}{0.147} \\
\hline & GES & $3.14 \pm 2.25$ & $3.37 \pm 2.58$ & & \\
\hline \multirow{2}{*}{ Alpha 2} & $\mathrm{GC}$ & $2.49 \pm 1.54$ & $2.31 \pm 1.57$ & \multirow{2}{*}{0.079} & \multirow{2}{*}{0.709} \\
\hline & GES & $3.85 \pm 2.23$ & $3.88 \pm 2.54$ & & \\
\hline \multirow{2}{*}{ Alpha 3} & GC & $2.32 \pm 1.96$ & $2.97 \pm 2.44$ & \multirow{2}{*}{0.089} & \multirow{2}{*}{0.434} \\
\hline & GES & $5.20 \pm 4.20$ & $5.18 \pm 4.72$ & & \\
\hline \multirow{2}{*}{ Alpha 4} & GC & $2.89 \pm 2.17$ & $4.47 \pm 2.86$ & \multirow{2}{*}{0.197} & \multirow{2}{*}{0.185} \\
\hline & GES & $5.93 \pm 5.24$ & $5.61 \pm 4.49$ & & \\
\hline
\end{tabular}

Note: Mean \pm Standard deviation. GC control group; GES: experimental group (scoliosis "S").

Table 5 - Analyses of postural angles with respect to the group and shim factors between the control and experimental "C" groups in the static condition with left shim

\begin{tabular}{|c|c|c|c|c|c|}
\hline \multirow[t]{2}{*}{ Postural Angles ( $\left(^{\circ}\right)$} & \multirow[t]{2}{*}{ Group } & \multicolumn{2}{|c|}{ Shim } & \multicolumn{2}{|c|}{ p-value (ANOVA) } \\
\hline & & Low & High & p-group & p-shim \\
\hline \multirow{2}{*}{ Alpha 1} & $\mathrm{GC}$ & $2.22 \pm 1.36$ & $2.51 \pm 1.39$ & \multirow{2}{*}{0.107} & \multirow{2}{*}{0.253} \\
\hline & GES & $4.47 \pm 3.64$ & $4.57 \pm 3.96$ & & \\
\hline \multirow{2}{*}{ Alpha 2} & $\mathrm{GC}$ & $2.49 \pm 1.54$ & $2.31 \pm 1.57$ & \multirow{2}{*}{0.087} & \multirow{2}{*}{0.168} \\
\hline & GES & $4.36 \pm 2.59$ & $4.05 \pm 2.98$ & & \\
\hline \multirow{2}{*}{ Alpha 3} & $\mathrm{GC}$ & $2.32 \pm 1.96$ & $2.97 \pm 2.44$ & \multirow{2}{*}{0.440} & \multirow{2}{*}{0.372} \\
\hline & GES & $3.55 \pm 3.63$ & $3.93 \pm 4.66$ & & \\
\hline \multirow{2}{*}{ Alpha 4} & GC & $2.89 \pm 2.17$ & $4.47 \pm 2.86$ & \multirow{2}{*}{0.323} & \multirow{2}{*}{$0.018^{*}$} \\
\hline & GES & $5.18 \pm 6.28$ & $6.66 \pm 7.14$ & & \\
\hline
\end{tabular}

Note: Mean \pm Standard deviation. GC: control group; GES: experimental group (scoliosis "C"); ${ }^{*}$ Significant difference ( $\left.\leq 0.05\right)$.

\section{Discussion}

Scoliosis with Cobb angle above $10^{\circ}$ degrees characterizes structural curves $(24,25,26)$. Nevertheless, some studies $(24,32,33)$ consider differences greater than $7^{\circ}$ as being important to point out significant asymmetries in the spine, and still others $(34,35)$ consider values above $5^{\circ}$. Although this form of measuring scoliosis is different from that used in the present study to measure the postural angles, both can be related as they use the same unit of measurement in degrees to identify asymmetries of the spine (23).

The results presented (Table 1) demonstrated that in the GES the mean of the alpha 3 and 4 angles, presented values higher than $5^{\circ}$, therefore considered as scoliosis. However, the alpha 2 value presented a significant result, although lower than $5^{\circ}$ for the GES and GEC, with values similar to other studies $(22$, 36). Therefore, it is suggested from these results that postural angles below $5^{\circ}$ may also represent important asymmetry of the spine.

The largest standard deviation values (Table 1) are related to the oscillation of the participants and the variation in the different degrees of deformity; the largest deviations were observed in patients with idiopathic scoliosis. Several authors have also observed this ratio of the largest fluctuations in the static position in the scoliotic subjects $(8,37-39)$, and the increase in oscillation indicates a deficit in static equilibrium (40). For simple curves a hierarchical difference has been established (40), wherein the curves in the lumbar and thoracolumbar segments are more unstable compared to those located in the upper and middle thoracic segments.

In the present study, the lower curves in the GES presented the lowest degree of Cobb angle, in addition to a higher oscillation value, represented by the mean values of standard deviation. This indicates an 
adaptation of the smaller and lower curves to stabilize the largest and highest curves, compensating them through their higher residual flexibility (41).

Furthermore, it can be seen that the apexes of the bends are the most asymmetric points with respect to the axis of the spine in the frontal plane. Therefore, the type of curve, thoracic and lumbar for the GES and thoracolumbar for the GEC, determined the significant differences in the alpha 2 and 4 angles, as the apexes were located in these regions.

According to Hawes \& O'Brien (41) the secondary or compensatory curves are more flexible and could present major alterations when subjected to manipulation by shims. Other studies $(23,41,42)$ point out that the vertebral segment located in the transition of the thoracic and lumbar curves presents vertebrae that accompany them, indicating that this region could be more flexible, being less affected by the deformity of the vertebrae at the apex of the main curve, promoting asymmetries in adjacent regions.

The results demonstrated that the lowest angles suffered the greatest influence from manipulation with the shims, with the highest mean values for the single and double curves. Therefore, it can be seen that there is an ascending alteration in the scoliotic curves, with the lumbar region being most affected $(9,15,23)$.

In the conditions low and high shims placed under the right foot (Table 2) of the participants of the GES, the largest curves were the thoracic curves, and consequently, these were more likely to be the principal curves. Therefore, the greatest effects of the shims were expected in the secondary curves (41), which are the lowest (15), as seen in the alpha 4 angle. In addition, the greater the shim height, the greater the asymmetry caused, observed primarily in alpha 3 and 4 .

For the GEC (Table 3), it can be seen that the alpha 1, 2 and 4 angles presented an increase in the mean values, becoming more asymmetric, while the alpha 3 angle showed a rectification verified by the reduction in mean value. Taking into consideration the predominance of left curves, the use of the right shim caused an accentuation of the curves, being that the ends of the spine, the high thoracic and lumbar regions, became more inclined.

The greater quantity of curves in the lumbar scoliosis in $\mathrm{S}$ and thoracolumbar scoliosis in $\mathrm{C}$ with convexity to the left, could have determined the behavior of the postural angles in the experimental groups similar to those of the control group (Tables 4 and 5). This effect is similar to the hitch exercise program ("shim simulation exercise") proposed by Maruyama et al. (7), where the use of the shim on the lower limb on the same side as the convexity of the lumbar and thoracolumbar curves favors its correction through contraction of the muscles for the homolateral vertebral. The study by Zabjek et al. (13) indicated that the implementation of insoles, regardless of the type and amplitude of the curve, if placed under the member on the lower side of the pelvic tilt, significantly reduces the Cobb angle.

In general, when the shim is placed under one foot, we can see that the greatest influence occurs in lower postural alpha angles, in the double and simple curves, and the alpha 4 angle is more influenced. The differences were mainly in relation to the groups, showing that these angles were always higher in the experimental groups. This result confirms that the shim has an effect in the lower regions of the spine and also in those least affected by deformity at the apex of the scoliosis curves, in this case being more likely to be influenced by the corrective effect of the shims, even in structural scoliosis. However, it is suggested that in double and single scoliosis any alteration in the support base that modifies the symmetry of the trunk, could cause reorganization of structures and a new arrangement of balance or compensatory adjustments in other segments of the trunk.

\section{Conclusion}

The fundamental base of rehabilitation programs is flexibility and postural readjustments, aimed at aligning the spine and whole body. These corrective manipulations should also be included in treatment of idiopathic scoliosis during adolescence or even after bone maturity. Clearly the results indicate that even in cases with scoliosis there is flexibility and adaptation, and therefore postural reorganization is susceptible to these manipulations.

\section{References}

1. Asher MA, Burton DC. Adolescent idiopathic scoliosis: natural history and long-term treatment effects. Scoliosis. 2006;1(1):2.

2. Bagnal KM. Using a synthesis of the research literature related to the etiology of adolescent idiopathic scoliosis to provide ideas on future directions for success. Scoliosis. 2008;3:5. 
3. Romano M, Minozzi S, Zaina F, Saltikov JB, Chockalingam N, Kotwicki T, et al. Exercises for Adolescent Idiopathic Scoliosis: A Cochrane Systematic Review. Spine (Phila Pa 1976). 2013;38(14):E883-93.

4. Kendall FP, Mccreary EK, Provance PG. Músculos provas e funções: com postura e dor. 4th ed. São Paulo: Manole; 2007. p. 121-9. Portuguese.

5. Stehbens WE, Cooper RL. Regression of juvenile idiopathic scoliosis. Exp Mol Pathol. 2003;74(3):326-35.

6. Romano M, Negrini S. Manual therapy as a conservative treatment for adolescent idiopathic scoliosis: a systematic review. Scoliosis. 2008;3:2.

7. Maruyama T, Kitagawa T, Takeshita K, Mochizuki K, Nakamura K. Conservative treatment for adolescent idiopathic scoliosis: can it reduce the incidence of surgical treatment. J Pediatr Rehabil. 2003;6(3-4):215-9.

8. Nault ML, Allard P, Hinse S, Le Blanc R, Caron O, Labelle H. Sadeghi, H. Relations between standing stability and posture parameters in adolescents idiopathic scoliosis. Spine (Phila Pa 1976). 2002;27(17):1911-7.

9. Ferreira EI, Ávila CAV, Mastroeni MF. Use of custom insoles for redistributing plantar pressure, decreasing musculoskeletal pain and reducing postural changes in obese adults. Fisioter Mov. 2015;28(2):213-21

10. Carlson BB, Burton DC, Asher MA. Comparison of trunk and spine deformity in adolescent idiopathic scoliosis. Scoliosis. 2013;8(1):2.

11. Beaudoin L, Zabjek KF, Leroux MA, Collard C, Rivard $\mathrm{CH}$. Acute systematic and variable postural adaptations induced by orthopaedic shoe lift in control subjects. Eur Spine J. 1999;8(1):40-5.

12. Nakajima K, Kakihana W, Nakagawa T, Mitomi H, Hikita A, Suzuki R, et al. Addition of an arch support improves the biomechanical effect of a laterally wedged insole. Gait Posture. 2009;29(2):208-13.

13. Zabjek KF, Leroux MA, Coillard C, Martinez X, Griffet J, Simard G, Rivard C-H. Acute postural adaptations induced by a shoe lift in idiopathic scoliosis patients. Eur Spine J. 2001;10:107-113.

14. Kim YM, Kim DS, Choi ES, Shon HC, Park KJ, Kim YS. The Effect of Shoe Lift on Lumbar Scoliosis Associated with Pelvic Obliquity. J Korean Soc Spine Surg. 2004;11(2):104-12.
15. Irvin RE. Reduction of lumbar scoliosis by use of a heel lift to level the sacral base. J Am Osteopath Assoc. 1991;91(1):34-44.

16. Tribastone F. Tratado de exercícios corretivos aplicados à reeducação motora postural. São Paulo: Manole; 2001. p. 213-308. Portuguese.

17. Ferreira DMA, Suguikawa TR, Pachioni CAS, Fregonesi CEPT, Camargo MR. Rastreamento escolar da escoliose: medida para o diagnóstico precoce. Rev Bras Crescimento Desenvolv Hum. 2009;19(3):357-68.

18. Ferreira DMA, Fernandes CG, Camargo MR, Pachioni CAS, Fregonesi CEPT, Faria CRS. Avaliação da coluna vertebral: relação entre gibosidade e curvas sagitais por método não-invasivo. Rev bras cineantropom desempenho hum. 2010;12(4):282-9.

19. Surós J. Semiologia médica y técnica exploratória. Barcelona: Salvat; 1977. p. 949-68. Spanish.

20. Ferreira DMA, Defino HLA. Avaliação quantitativa da escoliose idiopática: concordância das mensurações da gibosidade e correlações com medidas radiológicas. Rev Bras Fisioter. 2001;5(2):73-86.

21. Hresko MT. Clinical Practice. Idiopathic scoliosis in adolescents. N Engl J Med. 2013;368(9):834-41.

22. Haje SA, Haje DP, Guerra JB, Petrenko Jr AG. Órtese inclinada de uso continuo e exercícios para tratamento da escoliose idiopática: uma nova proposta. Brasilia Med. 2008;45(1):10-20.

23. Ferreira DMA, Barela JA. Análise da influência do calço e do movimento de inclinação lateral da coluna vertebral em indivíduos com escoliose idiopática [dissertation]. Rio Claro (Brazil): Universidade Estadual Paulista; 2009. 178 p. Portuguese.

24. Huang SC. Cutt-off point of the scoliometer in school scoliosis screening. Spine (Phila Pa 1976). 1997;22(17):1985-9.

25. Coelho DM, Bonagamba GH, Oliveira AS. Scoliometer measurements in patients with idiopathic scoliosis. Braz J Phys Ther. 2013;17(2):179-84.

26. Soucacos PN, Soucacos PK, Zacharis K, Beris AE, Xenakis TA. School-screening for scoliosis: a prospective epidemiological study in northwestern and central Greece. J Bone Joint Surg Am. 1997;79(10):1498-503. 
27. Salate ACB, Aroni FC, Ferreira DMA. Estudo da evolução a curto prazo da escoliose por meio de mensurações da gibosidade, radiográficas e da dor em adolescentes e adulto jovens. Rev Bras Fisioter. 2003;7(1):39-44.

28. Engsberg JR, Lenke LG, ReitenbachAK, Hollander KW, Bridwell KH, Blanke K. Prospective evaluation of trunk range of motion in adolescents with idiopathic scoliosis undergoing spinal fusion surgery. Spine. 2002;27(12):1346-54.

29. Feipel V, Aubin CE, Ciolofan OC, Beauséjour M, Labelle $\mathrm{H}$, Mathieu PA. Electromyogram and kinematic analysis of lateral bending in idiopathic scoliosis patients. Med Biol Eng Comput. 2002;40(5):497-505.

30. Leroux MA, Zabjek K, Simard G, Badeaux J, Coillard C, Rivard C. A noninvasive anthropometric technique for measuring kyphosis and lordosis - an application for idiopathic scoliosis. Spine. 2000;25(13):1689-94.

31. Gonzalez LJ, Sreenivasan SV, Jensen JL. A procedure to determine equilibrium postural configurations for arbitrary locations of the feet. J Biomech Eng. 1999;121(6):644-9.

32. Bunnell WP. Outcome of spinal screnning. Spine. 1993;18(12):1572-80.

33. Hackenberg L, Hierholzer E, Bullmann V, Liljenqvist U, Gotze C. Rasterstereographic analysis of axial back surface rotation in standing versus forward bending posture in idiopathic scoliosis. Eur Spine J. 2006;15(7):1144-9.

34. Stokes IAF, Armstrong JG, Moreland MS. Spinal deformity and back surface assimetry in idiopathic scoliosis. J Orthop Res. 1988;6(1):129-37.

35. Panchmatia JR, Isaacb A, Muthukumarc T, Gibsonc AJ, Lehovskyc J. The 10 key steps for radiographic analysis of adolescent idiopathic scoliosis. Clin Radiol. 2015;70(3):235-42.

36. Gram MC, Hasan Z. The spinal curve in standing and sitting postures in children with idiopathic scoliosis. Spine. 1999;24(2):169-77.

37. Beaulieu M, Toulotte C, Gatto L, Rivard CH, Teasdale N, Simoneau M, et al. Postural imbalance in non-treated adolescent idiopathic scoliosis at different periods of progression. Eur Spine J. 2009;18(1):38-44.
38. Sahli S, Rebai H, Ghroubi S, Yahia A, Guermazi M, Elleuch $\mathrm{MH}$. The effects of backpack load and carrying method on the balance of adolescent idiopathic scoliosis subjects. Spine J. 2013;13(12):1835-42.

39. Dalleau G, Allard MS, Beaulieu M, Rivard CH, Allard P. Free moment contribution to quiet standing in able-bodied and scoliotic girls. Eur Spine J. 2007;16(10):1593-9.

40. Gauchard GC, Lascombes P, Kuhnast M, Perrin PP. Influence of different types of progressive idiopathic scoliosis on static and dynamic control. Spine (Phila Pa 1976). 2001;26(9):1052-8.

41. Hawes MC, O'brien JP. The transformation of spinal curvature into spinal deformity pathological processes and implications for treatment. Scoliosis. 2006;1(1):3.

42. Modi HN, Suh SW, Song HR, Yang JH, Kim HJ, Modi CH. Differential wedging of vertebral body and intervertebral disc in thoracic and lumbar spine in adolescent idiopathic scoliosis - a cross sectional study in 150 patients. Scoliosis. 2008;3:11.

Received in 08/12/2015 Recebido em 12/08/2015

Approved in 07/28/2016 Aprovado em 28/07/2016 